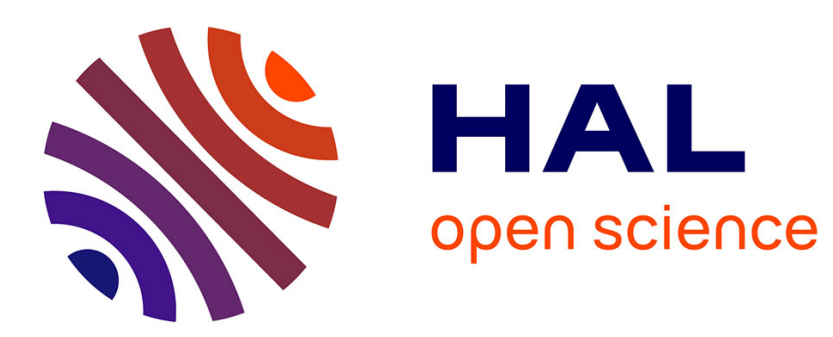

\title{
0.5-V 350-ps 28-nm FD-SOI SRAM Array with Dynamic Power-Supply 5T Cell
}

Khaja Ahmad Shaik, Kiyoo Itoh, Amara Amara

\section{To cite this version:}

Khaja Ahmad Shaik, Kiyoo Itoh, Amara Amara. 0.5-V 350-ps 28-nm FD-SOI SRAM Array with Dynamic Power-Supply 5T Cell. S3S, Jan 2016, Wine Country, SanFrancisco, United States. hal01254224

\section{HAL Id: hal-01254224 https://hal.science/hal-01254224}

Submitted on 11 Jan 2016

HAL is a multi-disciplinary open access archive for the deposit and dissemination of scientific research documents, whether they are published or not. The documents may come from teaching and research institutions in France or abroad, or from public or private research centers.
L'archive ouverte pluridisciplinaire HAL, est destinée au dépôt et à la diffusion de documents scientifiques de niveau recherche, publiés ou non, émanant des établissements d'enseignement et de recherche français ou étrangers, des laboratoires publics ou privés. 


\title{
0.5-V 350-ps 28-nm FD-SOI SRAM Array with Dynamic Power-Supply 5T Cell
}

\author{
Khaja Ahmad Shaik, Kiyoo Itoh, and Amara Amara \\ Institut supérieur d'électronique de Paris (ISEP), 10 Rue Vanves, Issy-les-Moulineaux, France. kshaik@isep.fr
}

\begin{abstract}
To achieve high-speed 0.5-V SRAMs, a dynamic power-supply $5 \mathrm{~T}$ cell, and a multi-divided array with selectivelyboosted 5T-cell power lines are proposed. Layout and post-layout simulation with a 28-nm planar-FD-SOI MOSFET reveal that a 4-kb array in a 128-kb core using the proposals operates at 350ps cycle with $x 6$ faster and $x 13$ lower power than the counterpart 6T-cell array, while maintaining a small leakage current.
\end{abstract}

Keywords-0.5-V dynamic power-supply $5 T$ cell, multi-divided open bit-line SRAM, selectively boosted cell-power lines.

\section{INTRODUCTION}

Traditional high-speed 6T-cell SRAMs are facing at least two issues, namely, voltage $\left(V_{\mathrm{DD}}\right)$ scaling of the cell to $0.5 \mathrm{~V}$ or less, and reduction of the array power. Recently, to solve the issues, a static multi-power-supply $5 \mathrm{~T}$ cell and a multi-divided open-BL (O-BL) array [1] are proposed. However, write speed is slow due to need for high- $V_{\mathrm{t}}$ MOSFETs for low standby leakage current. In this paper, to cope with the issues, a dynamic power-supply 5T cell (D-5T) and a multi-divided array with selectively-boosted D-5T power lines are proposed, and evaluated through layout and post-layout simulation with a 28-nm planar FD-SOI MOSFET [2].

\section{DYNAMIC POWER-SUPPLY 5T CELL}

Fig. 1 shows the proposed D-5T. The flip-flop in D-5T operates at one set of static supply $V_{\mathrm{DD}}$ and $V_{\mathrm{SS}}(=0 \mathrm{~V})$ and the other set of dynamic supply $V_{\mathrm{DH}}\left(\geq V_{\mathrm{DD}}\right)$ and $-V_{\mathrm{SL}}(\leq 0)$. In the standby mode, the power lines DHL and SLL are at $V_{\mathrm{DD}}$ and $V_{\mathrm{SS}}$, respectively. Here, it is assumed that each MOSFET has a regular $V_{\mathrm{t}}(=\mathrm{RVT} \cong 0.4 \mathrm{~V})$ so as to meet the leakage specification. In the active mode, they are positively and negatively boosted by $\Delta$ from $V_{\mathrm{DD}}$ and $V_{\mathrm{SS}}$. Hence, for example, when a cell storing " 0 " with $\mathrm{N}_{1}$ at $0 \mathrm{~V}$ is read, the gate-source (G-S) of on-MOSFET $\mathrm{M}_{\mathrm{d}}$ is forward-biased by $\Delta$ for quickly driving BL with the $V_{\mathrm{t}}$ effectively reduced to RVT $-\Delta$. That of off-MOSFET $\mathrm{M}_{1}$ is reverse-biased by $\Delta$ for lower leakage current with the $V_{\mathrm{t}}$ effectively increased to RVT $+\Delta$. Those of on-and -off MOSFETs $\left(\mathrm{M}_{\mathrm{lb}}\right.$ and $\left.\mathrm{M}_{\mathrm{db}}\right)$ are forward-biased by $\Delta$ with both $V_{\mathrm{t}} \mathrm{s}$ effectively reduced to $\mathrm{RVT}-\Delta$. Hence, although $\mathrm{M}_{\mathrm{lb}}$ enables faster write operation with faster feedback of the flip-flop, $M_{d b}$ increases the leakage current. Since such leakage is accepted with the array described later, faster read and write operations are achieved.
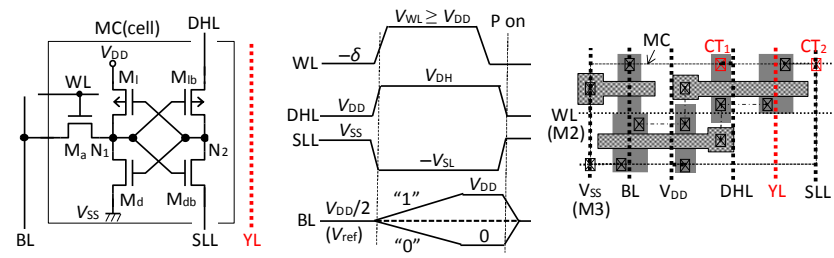

Fig. 1 Dynamic-power supply $5 \mathrm{~T}$ cell. $\mathrm{P}$; precharge. $\mathrm{CT}_{1}, \mathrm{CT}_{2}$; contacts.
D-5T is assisted by a negative and positive boosting of WL(NPB-WL) and mid-point sensing(MID-S). The negative boosting enables to reduce $V_{\mathrm{t}}\left(\mathrm{M}_{\mathrm{a}}\right)$ by $\delta$ for given leakage and $V_{\mathrm{WL}}$, further enhancing the speed. Unless WL is boosted, the speed is governed by $\mathrm{M}_{\mathrm{a}}$, losing the above-high-speed advantage of the flip-flop. Degraded read stability due to the $\mathrm{M}_{\mathrm{a}}-\mathrm{M}_{\mathrm{d}}$ ratio voltage increased by NPB-WL is remedied by reducing $\mathrm{BL}$-precharge voltage, $V_{\mathrm{P}}(\mathrm{BL})$, to $V_{\mathrm{DD}} / 2$, as mentioned later. Note that as long as cell nodes $\left(\mathrm{N}_{1}, \mathrm{~N}_{2}\right)$ stays at $V_{\mathrm{DD}}$, like in $6 \mathrm{~T}$, cell performances are almost governed by the flip-flop, regardless of WL and BL voltages. The $V_{\mathrm{DD}} / 2$ enables MID-S since it works as the reference voltage for " 1 " and " 0 " signal. MID-S halves the array dynamic power with halved BL-voltage swing. D-5T can be smaller than the $6 \mathrm{~T}$ due to one MOSFET and one BL eliminated from the 6T-cell layout [3]. It affords to add a contactless column line YL with the same layer as BLs and power lines in the 6T cell, which is indispensable for a high-performance array described later.

Fig. 2 shows parameters used for cell-evaluation. At $V_{\mathrm{t}}\left(\mathrm{M}_{\mathrm{lb}}\right) / V_{\mathrm{t}}\left(\mathrm{M}_{\mathrm{db}}\right)=342 / 468 \mathrm{mV}$, speeds become higher with higher $V_{\mathrm{DH}}$ and $V_{\mathrm{SL}}$ (see Fig. 3), as expected. Write operation becomes particularly faster with smaller $\Delta V_{\mathrm{t}}$ due to faster feedback of the flip-flop. Here, $\Delta V_{\mathrm{t}}$ denotes a deviation from the above $V_{\mathrm{t}} \mathrm{s}$. The write recovery is also fast, enabling fast write cycle time (see Fig. 4). In contrast, the $6 \mathrm{~T}$ cell using non-

\begin{tabular}{|c|c|c|}
\hline & $5 \mathrm{~T}$ & $6 \mathrm{~T}$ \\
\hline$V_{\mathrm{t}}\left(\mathrm{M}_{\mathrm{a}}\right) * / V_{\mathrm{t}}\left(\mathrm{M}_{\mathrm{ab}}\right)$ & $142 /-\mathrm{mV}$ & $342 / 342$ \\
\hline$V_{\mathrm{t}}\left(\mathrm{M}_{\mathrm{l}}\right) / V_{\mathrm{t}}\left(\mathrm{M}_{\mathrm{lb}}\right)$ & $217 / 342$ & $217 / 217$ \\
\hline$\left.V_{\mathrm{t}}\left(\mathrm{M}_{\mathrm{d}}\right) / V_{\mathrm{t}} \mathrm{M}_{\mathrm{db}}\right)$ & $393 / 468$ & $342 / 342$ \\
\hline$W\left(\mathrm{M}_{\mathrm{l}}\right) / W\left(\mathrm{M}_{\mathrm{lb}}\right)$ & $187 / 80 \mathrm{~nm}$ & $80 / 80$ \\
\hline$W\left(\mathrm{M}_{\mathrm{d}}\right) / W\left(\mathrm{M}_{\mathrm{db}}\right)$ & $80 / 80$ & $120 / 120$ \\
\hline Other $W \mathrm{~s}$ & $80 / 80$ & $80 / 80$ \\
\hline Cell size** & $928 \times 306 \mathrm{~nm}^{2}$ & $928 \times 306$ \\
\hline$V_{\mathrm{WL}} / \delta$ & $1 / 0.2 \mathrm{~V}$ & $0.5 / 0$ \\
\hline$V_{\mathrm{DD}} / V_{\mathrm{DH}} / V_{\mathrm{SL}}$ & $0.5 / 0.7 / 0.2 \mathrm{~V}$ & $0.5 / 0.5 / 0$ \\
\hline BL precharge & $0.25 \mathrm{~V}$ & 0.5 \\
\hline
\end{tabular}

(a) *saturation-current $V_{\mathrm{t}}, * * \log i c$ design rule, $L=30 \mathrm{~nm}$.

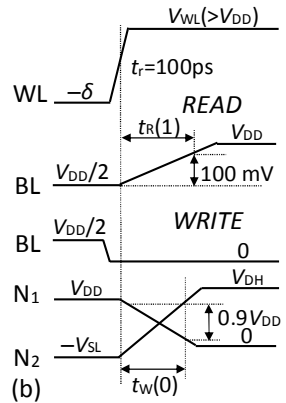

Fig. 2 (a) Typical design parameters of 5T cell and 6T cell[3], and (b) speed definitions, exemplified by $t_{\mathrm{R}}(1)$ for " 1 " read and $t_{\mathrm{W}}(0)$ for " 0 " write.
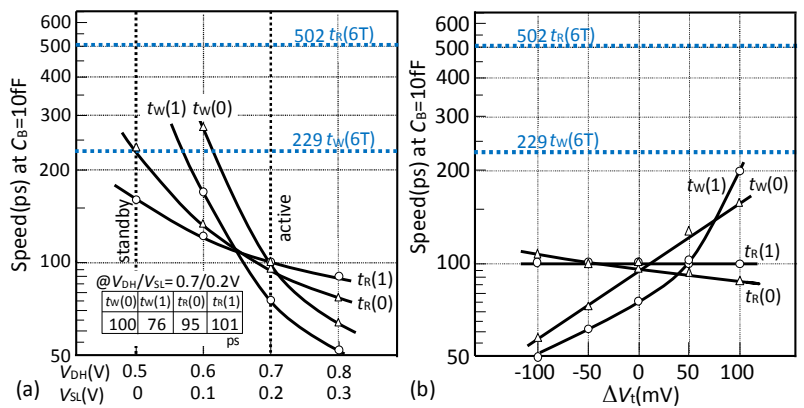

Fig. 3 Speeds for (a) $V_{\mathrm{DH}} / V_{\mathrm{SL}}$ for $\Delta V_{\mathrm{t}}=0 \mathrm{mV}$, and (b) $\Delta V_{\mathrm{t}}$ for $V_{\mathrm{DH}} / V_{\mathrm{SL}}=0.7 / 0.2$ V. $V_{\mathrm{t}}\left(\mathrm{M}_{\mathrm{lb}}\right)=342 \mathrm{mV}+\Delta V_{\mathrm{t}}$, and $V_{\mathrm{t}}\left(\mathrm{M}_{\mathrm{db}}\right)=468 \mathrm{mV}+\Delta V_{\mathrm{t}}$ 

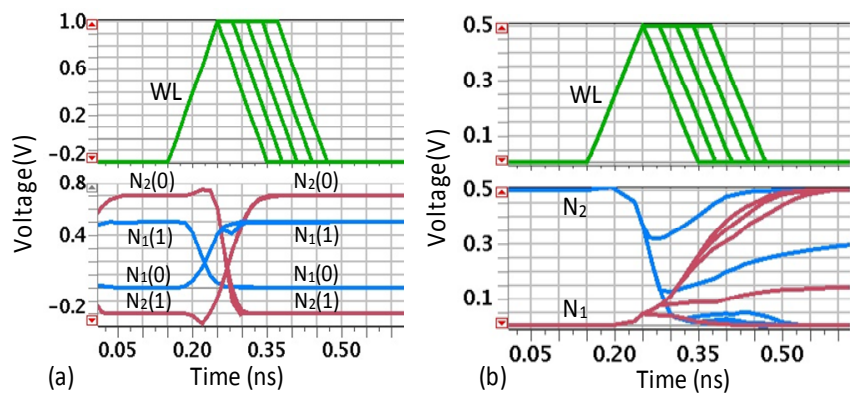

Fig. 4 Write waveforms of (a) D-5T and (b) 6T for various WL-pulse widths. $V_{\mathrm{DH}} / V_{\mathrm{SL}}=0.7 / 0.2 \mathrm{~V}$ and $\Delta V_{\mathrm{t}}=0 \mathrm{mV}$ for D-5T.
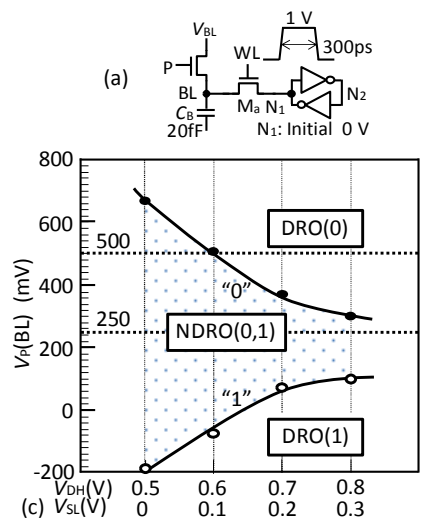
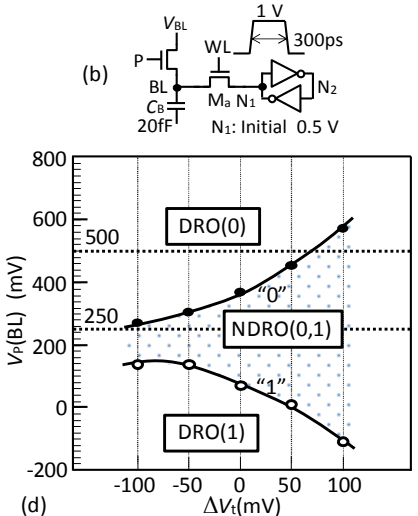
${ }_{20 \mathrm{fF}} \mathrm{M}_{\mathrm{N}} \mathrm{MaN}_{1}$ Initial $0.5 \mathrm{~V}$

Fig. 5 Read stability for (a) $V_{\mathrm{DH}} / V_{\mathrm{SL}}$ at $\Delta V_{\mathrm{t}}=0$, and (b) $\Delta V_{\mathrm{t}}$ at $V_{\mathrm{DH}} / V_{\mathrm{SL}}=0.7 / 0.2$ $\mathrm{V}$.
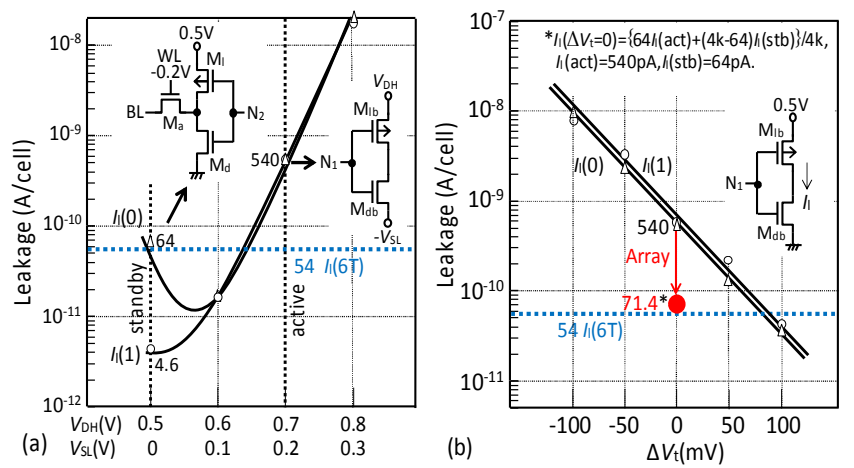

Fig. 6 Leakage current for (a) $V_{\mathrm{DH}} / V_{\mathrm{SL}}$ at $\Delta V_{\mathrm{t}}=0$, and (b) $\Delta V_{\mathrm{t}}$ at $V_{\mathrm{DH}} / V_{\mathrm{SL}}=$ $0.7 / 0.2 \mathrm{~V} . V_{\mathrm{t}}\left(\mathrm{M}_{\mathrm{lb}}\right)=342 \mathrm{mV}+\Delta V_{\mathrm{t}}$, and $V_{\mathrm{t}}\left(\mathrm{M}_{\mathrm{db}}\right)=468 \mathrm{mV}+\Delta V_{\mathrm{t}}$.

boosted WL and $V_{\mathrm{DD}}-\mathrm{BL}$ precharging is slow. Fig. 5 depicts the dynamic read stability, evaluated with actual relevant circuits (Figs. 5(a) and (b)) with a BL-capacitance $C_{\mathrm{B}}$ of $20 \mathrm{fF}$ and WL-pulse width of 300 ps. The shadowed area is for nondestructive read-out (NDRO) region for " 1 " and " 0 " read, while the white area for destructive read-out (DRO) region. Obviously, at $V_{\mathrm{P}}(\mathrm{BL})=V_{\mathrm{DD}} / 2(\mathrm{HVP}), \mathrm{D}-5 \mathrm{~T}$ is stable over a wide range of $V_{\mathrm{DH}} / V_{\mathrm{SL}}$ or $\Delta V_{\mathrm{t}}$. For $V_{\mathrm{P}}(\mathrm{BL})=V_{\mathrm{DD}}(\mathrm{FVP})$, however, NDRO is not ensured at $V_{\mathrm{DH}} / V_{\mathrm{SL}}>0.6 / 0.1 \mathrm{~V}$ or $\Delta V_{\mathrm{t}}<$ $70 \mathrm{mV}$, since the $\mathrm{M}_{\mathrm{lb}}-\mathrm{M}_{\mathrm{db}}$ inverter tends to more easily flip at the regions. Hence, HVP is mandatory to NDRO. Fig. 6 shows leakage characteristics. The major source of leakage is $\mathrm{M}_{\mathrm{lb}}$ or $\mathrm{M}_{\mathrm{db}}$ at a high- $V_{\mathrm{DH}} / V_{\mathrm{SL}}$ or small- $\Delta V_{\mathrm{t}}$ region while $\mathrm{M}_{1}$ or $\mathrm{M}_{\mathrm{d}}$ at a low $V_{\mathrm{DH}} / V_{\mathrm{SL}}$ or large- $\Delta V_{\mathrm{t}}$ region. The resultant large leakage of $\mathrm{M}_{\mathrm{lb}}$ or $\mathrm{M}_{\mathrm{db}}$ is accepted with the following array.

\section{Selectively-BoOsted CELl-Power-Line ARRAY}

Fig. 7 shows an O-BL 4-kb unit array [1] divided into four pairs of sub-arrays $\left(\mathrm{PMA}_{0}-\mathrm{PMA}_{3}\right)$, only one of which is activated for low power. The division is achieved without substantial area increase by sharing a large column block (YDEC\&DRV) with the PMAs, and leaving column selection to the YL. After equalizing all pairs of BLs, LIOs, and GIOs to $V_{\mathrm{DD}} / 2$, a signal is read out to the read and write circuit (RWC) through relevant switches (e.g., $\mathrm{My}_{0}$ and $\mathrm{My}_{0 \mathrm{~b}}, \mathrm{My}_{1}$ and $\mathrm{My}_{1 \mathrm{~b}}$, and $\mathrm{SW}_{0}$ ), and then amplified by RWC, referring to $V_{\mathrm{DD}} / 2$ at $/ \mathrm{GIOs}$. $V_{\mathrm{DH}}, V_{\mathrm{SL}}(=\delta=0.2 \mathrm{~V}), V_{\mathrm{DD}} / 2$, and $V_{\mathrm{WL}}\left(=V_{\mathrm{YL}}=\right.$ $1 \mathrm{~V})$ are assumed to be from on-chip voltage converters which are well established in DRAMs [4]. Additional area and power by $V_{\mathrm{DH}}$ and $V_{\mathrm{SL}}$ converters are expected to be insignificant at a $128-\mathrm{kb}$ core level, due to the small voltage swings and small leakage current.

For a given leakage current of array, the smaller the number of activated cells, the larger the allowable leakage current per activated cell, enabling faster write operation. In fact, the array meets the requirement if the multi-divided array is utilized. In principle, the number is reduced to 1/64 if one of 16 sets of the power lines (DHL and SLL) running in the BL direction is selected by a YL, and one-fourth each set divided into four, as in the figure, is selected by row addresses. The selection is performed by $3 \mathrm{D}$ selection, namely, activating a selected YL and a selected power-driver block PD of the four $\left(\mathrm{PD}_{0}-\mathrm{PD}_{3}\right)$ placed at the divisions. The $\mathrm{PD}$ outputs block power lines, BDH and BSL, to activate the row selector block SLB composed of many selector SLs, each of which is controlled by the YL and the set of BDH and BSL. Fig. 8 depicts selection-relevant circuits. A dual LIO and dual GIO structure is adopted to accommodate an SL in the BL pitch under two kinds of shared contacts (Fig. 1). Thus, for example, one set of $\mathrm{DHL}_{0}$ and $\mathrm{DHL}_{1}$, and $\mathrm{SLL}_{01}$, both of which connect 128 cells, are boosted by $\mathrm{YL}_{0}$ and the set of $\mathrm{BDH}_{0}$ and $\mathrm{BSL}_{0}$ from $\mathrm{PD}_{0}$. The number, however, is effectively 64 for a $128-\mathrm{kb}$ array with $32-\mathrm{b}$ data-in data-out organization. Leakage per cell in the active mode is thus reduced from $540 \mathrm{pA}$ to $71.4 \mathrm{pA}$ (i.e., only $11 \%$ larger than the standby leakage) at $\Delta V_{\mathrm{t}}=0$, as shown in Fig. 6, assuming that leakage current of a non-activated cell is $64 \mathrm{pA}$. The area penalty of SL is only $6 \%$ of the cell. Fig. 9 illustrates the

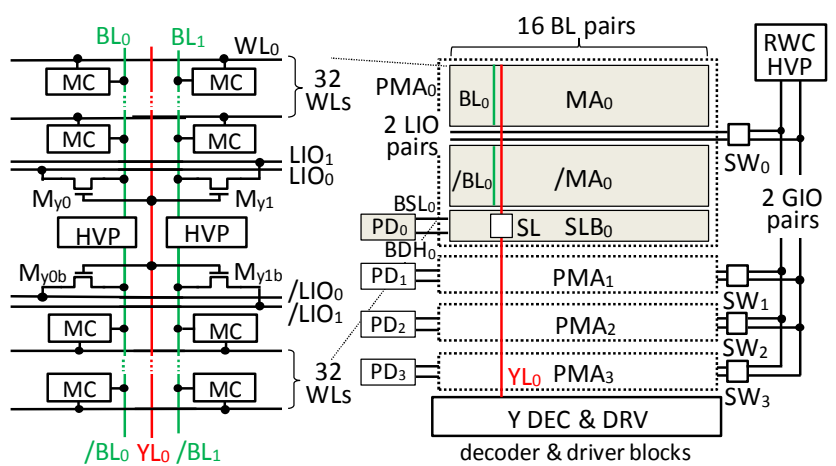

Fig. $74-\mathrm{kb}$ unit array in $128-\mathrm{kb}$ array with activating only $\mathrm{PMA}_{0}$. HVP: $V_{\mathrm{DD}} / 2$ precharger and equalizer. 


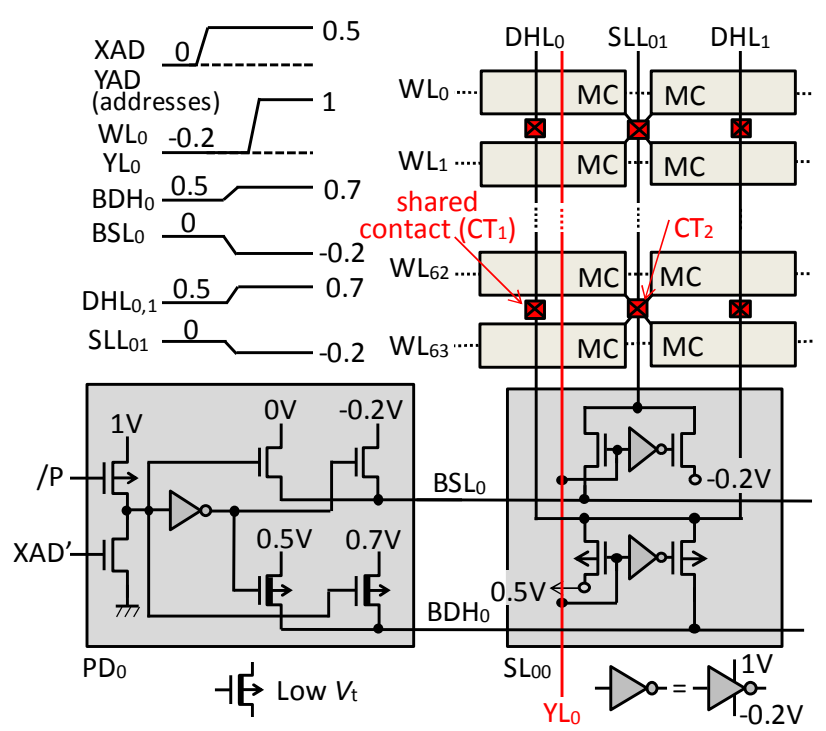

Fig. 8 Power driver (PD) and selector (SL).

$$
k-19.8 \mu \mathrm{m} \rightarrow
$$
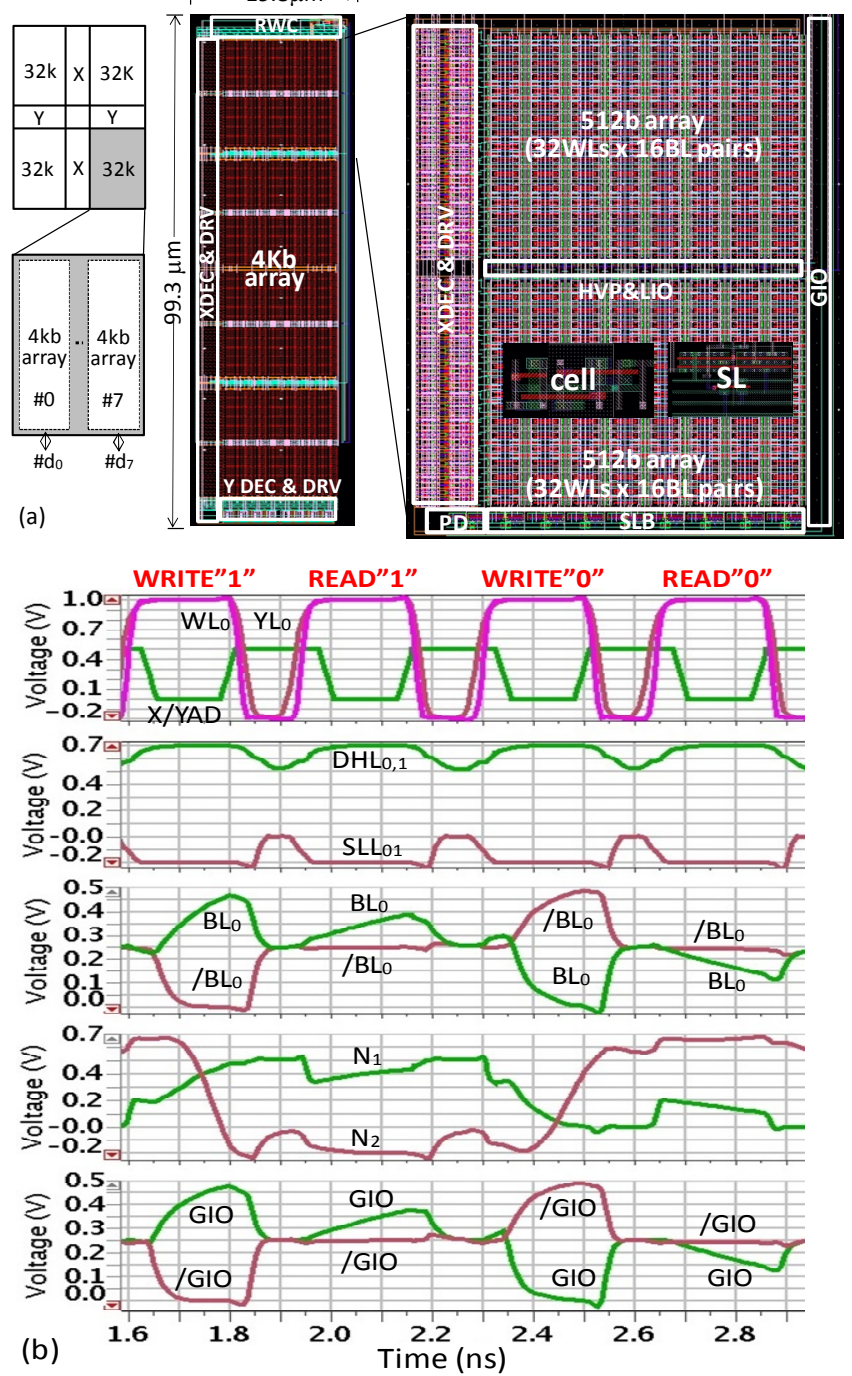

Fig. 9 (a) Layout and (b) waveforms of 4-kb unit array in 128-kb core. layout of the 4-kb unit array and waveforms by post-layout simulation, showing a fast cycle of $350 \mathrm{ps}$ enabled by fast write recovery, as expected. DHL- and SLL-waveforms are slightly deformed but quickly controlled. Indeed, as summarized in Fig. 10, the 5T-cell array is much faster than the 6T cell array due to excellent cell speeds and the small total capacitance $C_{\mathrm{T}}(\mathrm{R})$ of the read path thanks to the multidivided array. The cycle time is $\mathrm{x} 6$ faster because the $6 \mathrm{~T}$ array is as slow as $2 \mathrm{~ns}$. The active power is reduced to $1 / 13$ that of the 6T-cell array thanks to the small power-related total capacitance $C_{\mathrm{T}}(\mathrm{P})$ due to the partial activation of the array, and halved voltage swing on BLs, $\Delta V(\mathrm{BL})$. Here, no division for the 6T-cell array is assumed because the YL is not available. If divided with the same process, the array is intolerably large.

\begin{tabular}{|c|c|c|c|c|c|}
\hline \multirow{3}{*}{$\begin{array}{c}\text { Archit. of } \\
4-\mathrm{kb} \text { unit array } \\
V_{\mathrm{DD}}=0.5 \mathrm{~V} \\
V_{\mathrm{DH}}=0.7 \mathrm{~V} \\
V_{\mathrm{SL}}=0.2 \mathrm{~V} .\end{array}$} & \multicolumn{2}{|c|}{$5 T$} & \multicolumn{2}{|c|}{$6 \mathrm{~T}$} & \multirow[b]{3}{*}{ Remarks } \\
\hline & MA & $\mathrm{BL}$ & \multirow[b]{2}{*}{$\mathrm{BL}$} & \multirow[b]{2}{*}{ /BL } & \\
\hline & $\begin{aligned} \text { MA } \\
\end{aligned}$ & /BL & & & \\
\hline Cell size & $928 \times 3$ & $6 \mathrm{~nm}^{2}$ & \multicolumn{2}{|c|}{$928 \times 306 \mathrm{~nm}^{2}$} & Cell in Fig. 1 \\
\hline$C_{\mathrm{T}}(\mathrm{R})$ & \multicolumn{2}{|c|}{$15.8 \mathrm{fF}$} & \multicolumn{2}{|c|}{$37.6 \mathrm{fF}$} & simulated \\
\hline$t_{\mathrm{R}}(0) / t_{\mathrm{R}}(1)$ & \multicolumn{2}{|c|}{$179 / 176 p s$} & \multicolumn{2}{|c|}{$\cong 1,887 \mathrm{ps}^{* 1}$} & ${ }^{{ }^{*} 1}\left(C_{\mathrm{T}}(\mathrm{R}) / C_{\mathrm{B}}\right) t_{\mathrm{R}}$ (cell) \\
\hline$t_{w}(0) / t_{w}(1)$ & \multicolumn{2}{|c|}{$172 / 178 p s$} & \multicolumn{2}{|c|}{$\cong 331 \mathrm{ps}^{* 2}$} & ${ }^{2} t_{w}(6 \mathrm{~T})+102 \mathrm{ps}$ \\
\hline$t_{\mathrm{cmin}}($ ratio $)$ & \multicolumn{2}{|c|}{$350 p s(1)$} & \multicolumn{2}{|c|}{$\cong 2,058 \mathrm{ps}^{* 3}(5.9)$} & ${ }^{* 3} t_{\mathrm{R}}$ (array)+171ps \\
\hline$C_{\mathrm{T}}(\mathrm{P}) / \Delta V(\mathrm{BL})$ & \multicolumn{2}{|c|}{$85 \mathrm{fF} / 0.25 \mathrm{~V}$} & \multicolumn{2}{|c|}{$536 \mathrm{fF} / 0.5 \mathrm{~V}$} & \\
\hline$P_{\text {act }}$ (ratio) & \multicolumn{2}{|c|}{$1 / 12.6$} & \multicolumn{2}{|c|}{1} & worst $V_{\mathrm{t}}$-variation \\
\hline Leakstb/Leakact & \multicolumn{2}{|c|}{$262 / 293 n A$} & \multicolumn{2}{|c|}{$220 / 220 n A$} & \\
\hline
\end{tabular}

Fig. 10 Performances of 4-kb unit arrays in $128-\mathrm{kb}$ core. Simulated for 5T-cell array, while calculated for the 6T-cell array.

\section{CONCLUSION}

To achieve high-speed 0.5-V SRAMs, a dynamic powersupply $5 \mathrm{~T}$ cell, and a multi-divided array with selectivelyboosted 5T-cell power lines were proposed. Layout and postlayout simulation with a $28-\mathrm{nm}$ planar-FD-SOI MOSFET revealed that a $4-\mathrm{kb}$ array in a $128-\mathrm{kb}$ core using the proposals operates at 350-ps cycle with $\mathrm{x} 6$ faster and $\mathrm{x} 13$ lower power than the counterpart 6T-cell array, while maintaining a small leakage current.

\section{ACKNOWLEDGEMENT}

The authors thank Circuit Multi Projects (CMP), Grenoble, France for providing the FD-SOI $28 \mathrm{~nm}$ design kit (DK), and STMicroelectronics, Crolles, France for the DK support.

\section{REFERENCES}

[1] K. Itoh et al., "0.5-V Sub-ns Open-BL SRAM Array with Mid-PointSensing Multi-Power 5T Cell," ISCAS Proc. pp. 2892-2895, May 2015.

[2] P. Flatresse et al., "Ultra Wide Body Bias Range LDPC decoder in 28nm UTBB FDSOI Technology," ISSCC Dig., pp. 424-425, Feb. 2013.

[3] K. Osada et al.,"Universal-Vdd $0.65 \mathrm{~V}-2.0 \mathrm{~V} 32-\mathrm{kB}$ cache using a voltage-adapted timing-generation scheme and a lithographically symmetrical cell," JSSC, vol. 36, no. 11, pp.1738-1744, 2001.

[4] K. Itoh et al., Ultra-low Voltage Nano-scale Memories, Springer, pp. 277-279, 2007. 